\title{
Art Learning Using Collage Techniques in Inclusive Education Program
}

\author{
Dian Kencana* \\ Universitas Pendidikan Indonesia \\ Bandung, Indonesia \\ *Diankencana1907@gmail.com
}

\begin{abstract}
This article is based on the results of a literature study on review of fine art learning using collage techniques in inclusive education program. This article is aimed to answer three problems, namely the definiton, elements and uses of fine art using collage techniques in inclusive education program. In examining these three problems, the author used a literature review method from several sources of research results taken from textbooks, journals and articles, through the following stages: 1) Examining scientific works related to previous research results. 2) Classifying or grouping the concepts of reading materials. 3) Reciting it in the form of analysis of relevant scientific works. 4) Presenting it in table or matrix form. 5) Taking the extracts. Finding of this research, a hypothetical model about art learning using collage techniques in inclusive education program, that is it can increase social interaction, fine motor skills, concentration and creativity of inclusive students.
\end{abstract}

Keywords-collage techniques, inclusive education, art, student with disabilities

\section{INTRODUCTION}

Inclusive education means that schools must accommodate all children regardless of their physical, intellectual, social, emotional, language, or other conditions, including children with disabilities; gifted children (Children with gifted and Talented) child labor and street children; children in remote areas; children from ethnic and language minority groups; unlucky children; and marginalized from community groups [1].

With inclusive education, children with disabilities are educated with other normal children to optimize their potential [2].

An imbalance in physical growth and mental development affects developmental conditions. A child with a developmental disorder requires a learning strategy to handle developmental disorders as a child with special needs. Various characteristics or diversity of children with special needs require art learning as a forum for training skills in children's affective and motoric aspects [3]. Collage is one of the activities that can do to develop fine motor skills in inclusive students [4].
Muharrar and Verayanti explained that collage is a technique of sticking various elements into one frame to produce new artworks [5]. A collage is a two-dimensional work of art that uses a variety of materials as long as the raw material can combine with other raw materials, which can eventually unite into a complete work, so it can say that any material that can collaborate so that it becomes a twodimensional work of art can use as collage material. Visual elements contained in the collage include points and bits, lines, fields, colors, shapes, dark-light, and texture [6].

The objectives and benefits of Learning Fine Arts with Collage Techniques for inclusive children function as patterns in processing children's cognitive, affective and psychomotor aspects, namely training coordination of thoughts, feelings, and physical activities simultaneously, and being able to develop knowledge, learn and express their understanding through the form of artworks. So that inclusive students can think imaginatively, creatively, and can develop their intelligence.

The purpose of writing this article is

- To provide an explanation of learning fine arts with collage techniques

- An explanation of the elements of learning fine arts using collage techniques

- Explanation of the purpose and benefits of learning fine arts using collage techniques

\section{Methodology AND FramewORK OF THINKING}

\section{A. Methods}

The method used is the literature review, which is an essential part of a study. A literature review is a description of the literature relevant to a particular field or topic that gives a review of what has been discussed or talked by the researcher or writer. These hypothetical theories support and the research problem raised or asked [7].

The research subject is the Study of Learning Fine Arts with Collage Techniques in the Inclusive Education Program. 
Data analysis and collection techniques in this study refer to several sources, both textbooks, journals, and articles relevant to the research Sukardi [8], through the following steps:

- Review scientific papers related to previous research results.

- Classifying the concept of reading material.

- Re-describe in the form of analysis of relevant previous scientific works.

- Presented in table or matrix form

- Take Quintessence.

\section{B. Framework Thingking}

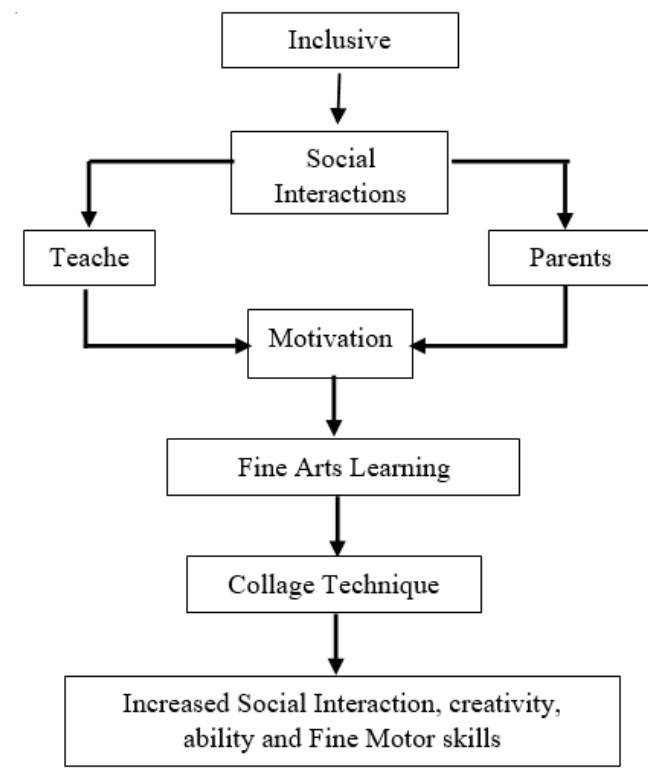

Fig. 1. Framework thinking.

In figure 1, inclusive students need encouragement to be achievers, and they are low self-esteem children [9] so that when they want to achieve and compete, they need support and motivation from those around them, teachers, and parents. As well as fine art study requires an explanation from teachers and parents of inclusive students.

Through collage techniques, art learning, can be more exciting and can improve creativity, concentration, social interaction, and fine motor skills in children at inclusive schools.

In learning fine arts using collage techniques, knowledge transfer carry out, developing creativity, increasing self-esteem, concentration, and fine motor skills. It will produce fine artworks with collage techniques by the outpouring of emotions and feelings.

\section{RESULTS AND DISCUSSION}

- The process of fine art learning with collage technique in inclusive education program gives guidance and information so that the children know many things such as definitions, elements and purposes, and benefits of fine arts learning with collage techniques in inclusive education programs.

- The fine art learning with collage techniques in inclusive education programs could increase social interaction and fine motor skills and increase the concentration and creativity of inclusive students.

- Fine art learning with collage technique in an inclusive education program is an effective way to express the children's self-esteem, mainly to express their feelings in their works and give them chances to develop their flexibility, self-esteem, social communication behavior. Other than that, it could be a way to better express their feelings and emotions, which could also increase their life quality.

\section{CONCLUSION}

Based on the finding results, it is generally concluded that the teachers can use this study's impact as a hypothetical learning model about fine art learning with collage technique in inclusive education programs in a way that regular and disability students have a group work to arrange meanings creatively.

Related to the children with disability conditions who have various limitations and learning needs; therefore, the implementations of the school's inclusive learning needs a curriculum modification, learning strategies, scoring system of learning results, and school management, which suitable for the service needs of children with disability.

The teachers can use the fine art learning with collage technique in inclusive education program as a learning method. Also, the teachers could modify the learning designs which more attractive for the students and also gives guidance and information to the inclusive students and teach the parents about fine arts with collage technique by using simple stuff to increase the social interactions, fine motor skills, concentrations and creativity of inclusive students.

\section{REFERENCES}

[1] I. Ishartiwi, "Implementasi Pendidikan Inklusif Bagi Anak Berkebutuhan Khusus Dalam Sistem Persekolahan Nasional," JPK (Jurnal Pendidikan Khusus), vol. 6, no. 2, 2010.

[2] UNESCO, Deklarasi Dunia tentang Pernyataan Salamanca Pendidikan untuk Semua, Jomtien tahun 1990. Kompendium Perjanjian, Hukum, dan Peraturan Menjamin Semua Anak Memperoleh Kesamaan Hak untuk Kualitas Pendidikan dalam Cara Inklusif. Jakarta: UNESCO Office, 2006

[3] V.R. Pebriani, Pengembangan Program Layanan Pendidikan Inklusif Bandung: Universitas Pendidikan Indonesia 
[4] R.F. Sari, "Pengertian Kolase Unsur Teknik dan Cara Membuatnya," 2019 [Online] Retrieved from https://www.idpengertian.com/pengertian-kolase/

[5] S. Muharrar and S. Verayanti, Kreasi Kolase, Montase, Mozaik Sederhana. Jakarta: Esensi, 2013.

[6] V.H. Kurnia, "Kegiatan Kolase Tiga Dimensi Terhadap Kemampuan Motorik Halus Anak Autis di TK," 2017. [Online] Retrieved from: https://jurnalmahasiswa.unesa.ac.id/index.php/jurnal-pendidikankhusus/article/view/19374
[7] P. Setyosari, Metode Penelitian Penelitian dan Pengembangan. Jakarta: Kencana, 2010

[8] H.M. Sukardi, Metodologi penelitian pendidikan kompetensi dan praktiknya. Jakarta: PT Bumi Aksara, 2003.

[9] A. Round, W.J. Baker, and C.S. Rayner, "Using visual arts to encourage children with Autism Spectrum Disorder to communicate their feelings and emotions," Open J. Soc. Sci., vol. 5, no. 10, pp. 90-108, 2017. 